Portland State University

PDXScholar

$11-2010$

\title{
Analysis of Bus Collision Incidents Using Transit ITS and other Archived Operations Data
}

James G. Strathman

Portland State University

Paul Herman Wachana

Portland State University

Steve Callas

TriMet

Follow this and additional works at: https://pdxscholar.library.pdx.edu/trec_reports

Part of the Transportation Commons, Urban Studies Commons, and the Urban Studies and Planning Commons

Let us know how access to this document benefits you.

\section{Recommended Citation}

Strathman, James, Paul Wachana and Steve Callas. Analysis of Bus Collision Incidents Using Transit ITS and other Archived Operations Data. OTREC-RR-10-15. Portland, OR: Transportation Research and Education Center (TREC), 2010. https://doi.org/10.15760/trec.33

This Report is brought to you for free and open access. It has been accepted for inclusion in TREC Final Reports by an authorized administrator of PDXScholar. Please contact us if we can make this document more accessible: pdxscholar@pdx.edu. 

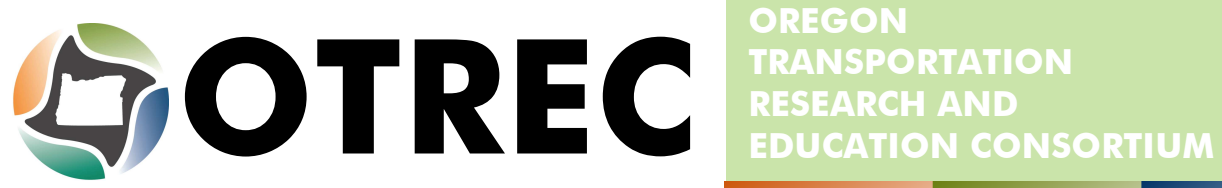

FINAL REPORT

\section{Analysis of Bus Collision and Non-Collision Incidents Using Transit ITS and other Archived Operations Data}

OTREC-RR-10-15

November 2010 



\title{
ANALYSIS OF BUS COLLISION AND NON-COLLISION INCIDENTS USING TRANSIT ITS AND OTHER ARCHIVED OPERATIONS DATA
}

\author{
Final Report \\ OTREC-RR-10-15 \\ by \\ James G. Strathman \\ Paul Wachana \\ Center for Urban Studies \\ Portland State University \\ Portland, OR 97207

\section{Steve Callas} \\ TriMet \\ 4012 S.E. $17^{\text {th }}$ Ave. \\ Portland, OR 97202
}

for

Oregon Transportation Research And Education Consortium (OTREC)

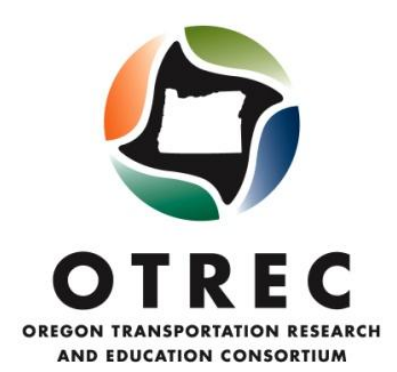

November 2010 



\begin{tabular}{|c|c|c|}
\hline \multicolumn{3}{|c|}{ Technical Report Documentation Page } \\
\hline $\begin{array}{l}\text { 1. Report No. } \\
\text { OTREC-RR-10-15 }\end{array}$ & 2. Government Accession No. & 3. Recipient's Catalog No. \\
\hline \multirow{2}{*}{\multicolumn{2}{|c|}{$\begin{array}{l}\text { 4. Title and Subtitle } \\
\text { ANALYSIS OF BUS COLLISION AND NON-COLLISION INCIDENTS USING } \\
\text { TRANSIT ITS AND OTHER ARCHIVED OPERATIONS DATA }\end{array}$}} & $\begin{array}{l}\text { 5. Report Date } \\
\text { November } 2010\end{array}$ \\
\hline & & 6. Performing Organization Code \\
\hline \multicolumn{2}{|c|}{$\begin{array}{l}\text { 7. Author(s) } \\
\text { James G. Strathman, Paul Wachana, and Steve Callas }\end{array}$} & 8. Performing Organization Report No. \\
\hline \multirow{2}{*}{\multicolumn{2}{|c|}{$\begin{array}{l}\text { 9. Performing Organization Name and Address } \\
\text { Center for Urban Studies } \\
\text { Portland State University } \\
\text { Portland, OR } 97207\end{array}$}} & 10. Work Unit No. (TRAIS) \\
\hline & & 11. Contract or Grant No. \\
\hline \multirow{2}{*}{\multicolumn{2}{|c|}{$\begin{array}{l}\text { 12. Sponsoring Agency Name and Address } \\
\text { Oregon Transportation Research } \\
\text { and Education Consortium (OTREC) } \\
\text { P.O. Box } 751 \\
\text { Portland, Oregon } 97207\end{array}$}} & 13. Type of Report and Period Covered \\
\hline & & 14. Sponsoring Agency Code \\
\hline
\end{tabular}

15. Supplementary Notes

16. Abstract

This report analyzes factors contributing to bus operations safety incidents at TriMet, the transit provider for the Portland Oregon metropolitan region. The analysis focuses on 4,631 collision and non-collision incidents that occurred between 2006 and 2009. Empirical analysis of these incidents draws on a wide array of operator-level data recovered by transit ITS technologies in combination with information from TriMet's human resources, scheduling, and customer relations databases. Incident frequencies are estimated in relation to operators' demographic

characteristics, employment status, assigned work characteristics, service delivery and performance indicators, temporal factors, and customer information. Apart from identifying factors that are empirically related to the frequency of safety incidents, the findings offer insights into operations policies and practices that hold promise for improving safety.

\begin{tabular}{l|l} 
17. Key Words & $\begin{array}{l}\text { 18. Distribution Statement } \\
\text { No restrictions. Copies available from OTREC: } \\
\text { www.otrec.us }\end{array}$ \\
\end{tabular}

19. Security Classification (of this report) 20. Security Classification (of this page) 21. No. of Pages 35 


\section{ACKNOWLEDGEMENTS}

The authors gratefully acknowledge the financial support provided by the Oregon Transportation Research and Education Consortium (OTREC) and by TriMet.

\section{DISCLAIMER}

The contents of this report reflect the views of the authors, who are solely responsible for the facts and the accuracy of the material and information presented herein. This document is disseminated under the sponsorship of the U.S. Department of Transportation University Transportation Centers Program and TriMet in the interest of information exchange. The U.S. Government and TriMet assume no liability for the contents or use thereof. The contents do not necessarily reflect the official views of the U.S. Government and TriMet. This report does not constitute a standard, specification, or regulation. 


\section{TABLE OF CONTENTS}

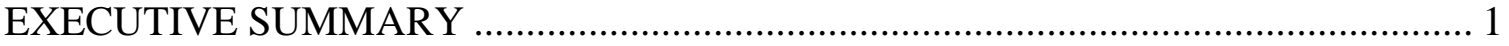

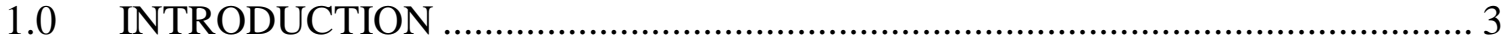

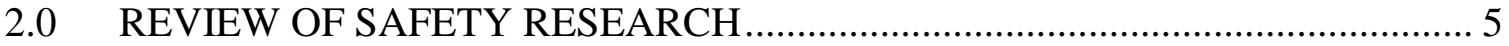

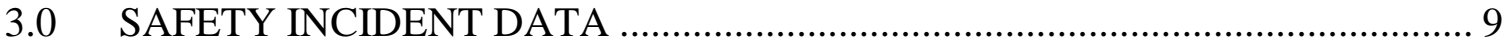

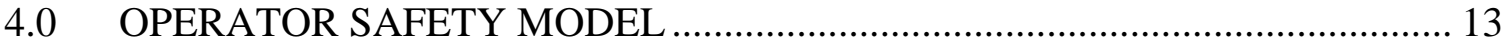

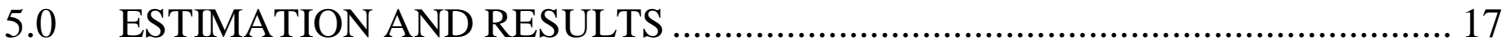

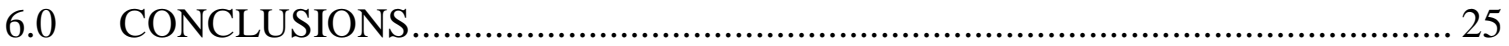

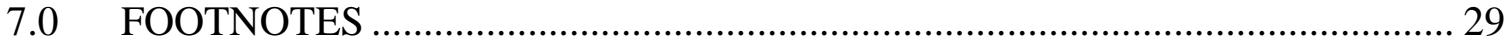

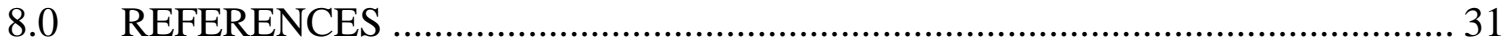

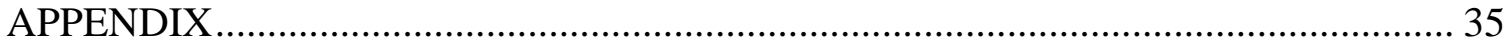




\section{EXECUTIVE SUMMARY}

This report examines collision and non-collision incidents associated with bus operations at TriMet. The analysis encompasses over 4,600 incidents that occurred between 2006 and 2009. Regression analysis is employed to estimate the effects of a variety of factors influencing the frequency of collision and non-collision incidents, including operator demographics, employment status, characteristics of assigned work, service delivery performance, and information provided by customers about their riding experiences. The principal findings and implications are summarized below.

First, beyond the initial probationary period of employment, the regression results indicate that there are diminishing marginal safety returns associated with both operator age and length of service, where the collision frequency elasticities become positive at age 30 and when length of service reaches 33 years. Regarding the age effect, traffic safety researchers have long recognized that drivers' motor and cognitive performance diminish with age, although the transition point estimated in this study occurs when bus operators are still relatively young.

This finding may not surprise those who have studied the health and wellness of transit operators. However, health and wellness research in the transit industry has tended to focus on such outcomes as health expenses, workers' compensation costs, absenteeism costs, and operator turnover costs (Davis, 2004). As this study's findings indicate, safety outcomes and costs should also be a relevant concern associated with the aging of operators. The diminishing marginal safety returns to operator length of service point to a need for more emphasis on regular refresher training, a practice that an industry survey by Moffat et al. (2001) found is utilized by only $36 \%$ of transit properties.

Second, operator absenteeism has been a long-standing focus of an industry concerned with containing health expenses and labor costs, as well as reducing labor turnover. Beyond these concerns, this study's findings indicate that absenteeism also contributes both directly and indirectly to safety outcomes and costs: directly in the positive association found between an operator's absence hours and his expected collision frequency, and indirectly through the absence-driven demand for extraboard replacement operators, whose more varied daily work spans are estimated to contribute to greater collision frequency.

Third, the transit safety literature has identified operator fatigue as a serious concern, and this study's findings offer support for this concern in several respects. Generally, collision and non-collision risk is greater during overtime shift hours. Also, when controlling for hours worked, increasing the daily span of hours - as is the case for splitshift operators - is estimated to increase the expected frequency of collisions. Fatiguerelated concerns associated with the disruptive effects of variable work assignments are 
also supported by the positive link estimated between work-span variability and expected collision frequency. Thus, expected labor cost savings that motivate the use of such work assignments are at least partially undermined by higher safety costs.

Fourth, operator surveys reveal that pressures to maintain a schedule are a key source of occupational stress. This study has found that running late is a significant contributor to the expected frequency of both collision and non-collision incidents. With the advent of AVL systems, schedule writers now have access to abundant running-time information, reducing the likelihood that running late is a consequence of a poorly written schedule. However, schedules are written to be compatible with the abilities of a "typical" operator (Levinson, 1991). The "variance" of abilities in relation to the typical operator means that some operators will face greater difficulty maintaining a schedule on a given route. Hypothetically, it would thus be beneficial to assign work so that such variance is minimized. However, it has been a time-honored (and bargained) right of operators to select work on the basis of seniority, which may or may not be compatible with a "minimum variance" alternative.

Fifth, related to operators' schedule maintenance pressures, additional dwell time associated with lift operations can be directly factored into schedules when the frequency of lift operations is regular and predictable. When lift usage is sporadic, it is commonly treated as another contributor to random delay, and is addressed indirectly in the recovery time that is built into a schedule. While the positive association between lift usage and expected collision frequency estimated in this study can be interpreted as a scheduling problem, more detailed analysis of lift activity at the route and trip levels would be needed to determine how the problem should be addressed in the schedule-writing process.

In addition, this study has found a positive association between lift usage and the expected frequency of non-collision incidents, suggesting that customers with disabilities face a relatively greater safety risk. This finding underscores a need for continuing research on the design of lift and securement devices, as well as a need for continuing assessment of practices intended to ensure safe travel among this customer cohort.

Sixth, customer commendations and complaints serve as a valuable source of information that can be used to improve safety. While operators are often rightfully skeptical of the validity of individual pieces of customer information, this study has found that patterns of customer information offer important insights into operators' safety-related performance. 


\subsection{INTRODUCTION}

U.S. transit systems provide a relatively safe means of travel for bus riders. For example, the American Public Transit Association reports that the fatality rate (standardized by passenger miles) for bus riders in 2003-2005 was only 2.8\% of the fatality rate for automobile travelers (APTA, 2009). Nevertheless, the safety risks for bus riders are relatively greater than the risks associated with other transit modes. Information reported to the Federal Transit Administration (FTA, 2009a) indicates that while buses accounted for $42.8 \%$ of transit passenger miles in 2007 , they were involved in $51.9 \%$ of the industry's safety incidents, $77.8 \%$ of all collisions, and $62.3 \%$ of all injuries. Fatalities (at $31.2 \%$ of the total) were the only underrepresented category. FTA analysis has also found that bus safety incident rates have been trending upward, with accident, injury and fatality rates increasing $171 \%, 37.8 \%$, and 5.1\%, respectively, between 2003 and 2007 (FTA, 2009b).

Reversing the upward trend in bus safety incidents is an important objective of both transit providers and the FTA. Central to this objective is a need to better identify and assess contributing factors that are within the control of transit providers, so that changes in practices can be made to improve safety. As FTA (2009b: 5) has stated, “... a transit bus system does have influence over how its bus operators perform their duties and can implement training and supervisory monitoring programs to improve operator safety related performance." Beyond the operator, a variety of factors relating to the planning and delivery of bus service affect safety performance and are also subject to managerial control (Technology and Management Systems, 2001).

Considerable insight has been gained from past safety research in the transit industry, as well as research focused more generally on commercial motor vehicles. Prior research has addressed safety in relation to operator demographics, stress and fatigue, measures of risk exposure, route features, operating conditions, and vehicle design.

While prior transit safety research has been valuable, it is important to recognize that the various human, physical, and environmental aspects of safety risk present in a busoperating environment are highly complex. Prior analyses of factors contributing to crashes and injuries have often fallen short of sufficiently representing this complexity, particularly with respect to the risk factors that are within the control of transit management. Data limitations have often compromised safety analysis in the transit industry, as reflected by overly aggregate research designs, or by model specifications that lack relevant variables or rely on variables that only roughly proxy safety risk.

The widespread deployment of intelligent transportation system (ITS) technologies in the transit industry over the past decade raises the potential for overcoming many of the data resource limitations that have inhibited prior safety research. Automatic vehicle location (AVL) systems are the "backbone" ITS technology, providing time and location referencing for monitoring passenger activity, as recorded by automatic passenger 
counters (APCs), as well as for a wide range of incidents recorded by operators on mobile data terminals (MDTs). AVL data are also useful in their own right for monitoring schedule and headway adherence, on-time performance, vehicle speeds, dwell times, running times, departure times, and layover times.

The highly detailed ITS data are commonly archived in an enterprise data warehouse. A typical transit data warehouse also maintains other databases that are potentially relevant to safety analysis. For example, a human resource database can add information about operator demographics, employment status, experience, and work attendance. An automated scheduling and run-cutting database can add detailed information about operators' assigned work, including vehicles, routes, days, time of day, and scheduled overtime. Lastly, a customer relations database can add information about customer reactions to their riding experience, including commendations of operators' performance on the job and complaints related to operators' treatment of passengers, handling of vehicles, or fitness for duty. Collectively, the information from such archived databases provides a comprehensive and highly detailed portrait of operators' qualifications, work environment, and performance.

This report draws on ITS and other data archived by TriMet, the transit provider for the Portland, OR, metropolitan area, to assess bus collision and non-collision incidents that occurred over a three-year period. TriMet can be characterized as a mid-sized urban transit system, providing fixed-route bus, light rail, and streetcar service. In 2008, its bus system carried 220,000 weekday boarding riders on a fleet of 542 peak vehicles, with 881 full-time and 331 part-time operators.

The remainder of the report is organized as follows: The next section presents a review of safety research related to this study, followed by a characterization of collision and non-collision incidents that occurred during the study period. An operator-based incident frequency model is then defined. Model estimation results are reported and, lastly, implications and conclusions of the analysis are presented. 


\subsection{REVIEW OF SAFETY RESEARCH}

Generally, traffic safety research has found negligent driver behavior to be the principal cause of crashes. Evans (2004), for example, summarizes the findings of two large independent studies undertaken in the U.S. and the UK Based on analysis of the details of thousands of crash records, both studies found driver behavior to be either the sole or contributing cause in over $90 \%$ of crashes. The principal causes of the remaining crashes were identified as vehicle failures (e.g., brakes and tires), environmental factors (e.g., weather and lighting), and roadway factors (e.g., design and condition).

The UK and U.S. crash studies covered general driving populations rather than professional operators. Nevertheless, the findings underscore the importance of training, experience, and safe operating practices in achieving safety improvements. More generally, one consequence of additional training and experience is the enhancement of operators' human capital. Returns to such human capital include increases in operator productivity as well as improvements in safety. Evidence consistent with the human capital perspective has been found in safety studies of the commercial trucking industry (e.g., Rodriguez et al. 2003; Krass, 1993; Monaco and Williams, 2000).

Safety risk has also been considered from an organizational perspective. Reason (1997) introduced a hierarchical framework wherein management's commitment to safety determines investments in workplace-level safety controls and practices. The extent of adherence to controls and practices, in turn, is reflected in the propensity of workers to engage in unsafe acts that, ultimately, are reflected in the incidence of accidents and injuries. This framework was employed by Arnold and Hartley (2001) in evaluating the management of driver fatigue problems, as well as by Chang and Yeh (2005) in assessing the safety consequences of intercity bus deregulation.

The conceptual framework developed by Jovanis et al. (1991) to explain transit accident risk corresponds most closely to the orientation of the present study. They treat accident risk as an outcome of the interaction among traditional safety determinants (i.e., human capital, vehicle factors, and roadway characteristics), transit service characteristics, and agency safety policies. Their approach is attractive because it can provide insight into safety performance at varying operational scales (i.e., from the route to the system level). However, it also has limitations. When accident analysis is organized around routes, it becomes difficult to assess both operator and situational factors within the same context. This may in part explain why the authors did not simultaneously consider characteristics of operators and their work in an analysis of bus accidents in suburban Chicago.

Passenger safety risk is a key concern within the transit industry. Injuries to transit passengers are often a consequence of non-collision incidents. Such incidents tend to occur during the process of boarding or alighting (Morlok et al., 2004; Hundenski, 1992) and during a vehicle's acceleration or deceleration phases (Wahlberg, 2007). The risk of boarding and alighting injuries may be less for "low-floor" and "kneeling" buses, 
especially for passengers with medical or physical impairments, as well as for those who are "under the influence." When operators consistently follow safe operating policies in securing passengers with mobility devices and waiting until passengers are securely on board before pulling out from a stop, the incidence of passenger injuries can be reduced.

Turning to work-specific issues, there has long been a concern in the transit industry about the safety consequences of operator fatigue (Gertler et al., 2002). Fatigue can be linked to selected work assignment practices in the industry. For example, rapid increases in fringe benefit costs have encouraged greater reliance on overtime rather than additional hires in order to control compensation costs. Similarly, splitting a full-time operator's shift between the a.m. and p.m. peak periods is less costly than covering each peak with a part-time operator. However, it also stretches the span of the operator's workday. Variability in shift-time assignments also contributes to fatigue. Such variability is most evident among operators who work the extraboard, which fills work assignments that are vacant due to absences.

The risks to operators from occupational stress are also a concern in the industry. An operator's job has been characterized as being typical of a high-stress occupation, with heavy work demands, low control, low support, and elevated incidence of chronic health problems (Kompier and Di Martino, 1995; Long and Perry, 1985; Winkleby et al., 1988). The job entails three principal responsibilities that are often in conflict: provide positive customer service, keep to a schedule, and drive safely. Operator surveys consistently identify stressors that act to undermine each of these responsibilities: heavy passenger loads and risk of assault; unpredictable delays related to traffic congestion and variable demand; and the difficulty of navigating a large vehicle in and out of the traffic stream to serve stops that are usually located at busy intersections (Long and Perry, 1985).

While the relationship between operator stress/fatigue and absence/health has been reasonably well documented, the logical extension to safety has not been very strongly established. A study by Wahlberg and Dorn (2009) represents an effort toward such an extension. They found a positive association between absence and accident frequencies among three independent samples of bus operators from the UK and Sweden. This finding led them to posit that absence frequencies might correspond to health conditions that diminish driving performance. Another interpretation may be drawn from the work of Strathman et al. (in press). Their study of U.S. bus operators found that absences spiked on the days before and after scheduled days off, which suggests that an association between accident and absence frequencies might also reflect the effects of low job satisfaction and commitment.

With respect to demographic and employment status attributes, crash incidence has been found to decline with operators' age (Dorn and Wahlberg, 2008; Jovanis et al., 1991; Zegeer et al., 1993). The effect of seniority was found to be non-linear by Jovanis et al. (1991), who reported that operators with three to six years of service were overrepresented in crashes relative to operators with greater or less seniority. Rodriguez et al. (2003) found that married, non-Caucasian, and women commercial truck operators were less likely to be involved in crashes. 
Research on crash risk related to operators' work schedules indicates that crash likelihoods are greater for morning than afternoon and evening shifts, as well as for split shifts (Pokorny et al., 1987a; Pokorny et al., 1987b). Alternatively, Gertler et al. (2002) state that crash risk tends to increase over the course of a workday. Hamed et al. (1998) found crash incidence to be inversely related to operators' break time.

The location and design of bus stops have been found to influence customer safety and crash risk. Stops located at the far side of intersections experience fewer crashes than near side or mid-block stops (Cheung et al., 2008; Texas Transportation Institute, 1996; Zegeer et al., 1993). Bus turn-out lanes have been recommended in moderate traffic volume situations, as have lighting upgrades and pedestrian facility improvements (Texas Transportation Institute, 1996).

Lastly, a number of measures have been employed or suggested to represent risk exposure. Such measures include vehicle hours and miles; passenger movements and stops served; route length, traffic volume, and number of intersections per route; and the extent of on-street parking (Cheung et al., 2008; Jovanis et al., 1991; Ragland et al., 1992). 


\subsection{SAFETY INCIDENT DATA}

The safety incident data for this study were retrieved from TriMet's Accident and Incident Tracking System, which is maintained in the agency's enterprise data warehouse. The records of all bus-involved safety incidents occurring from September 2006 through February 2009 were retrieved and reviewed. Records of incidents that did not occur within the platform-service time frame (i.e., between pull-out and pull-in) were deleted. Such incidents were mostly associated with bus maintenance, refueling, and "yard-spotting" activities. Also, records of safety incidents or injuries witnessed by an operator but not involving his or her bus were deleted. Further, two incident records are produced when collisions involving two buses occur. In these infrequent instances, the record in which the incident was coded as "preventable" was retained and the partner record was deleted. The resulting file consisted of 4,628 incident records.

A breakdown of the incidents is presented in Table 1. Collisions accounted for nearly $57 \%$ of the incidents. About half of the collisions involved another motor vehicle, and about two-thirds of these collisions were the result of another motor vehicle running into a bus. The second most frequent collision type involved mirror strikes. Compared to other collision types, the consequences of these incidents are relatively minor. Collisions with fixed objects were the third most common. The least common collisions involved pedestrians and bicyclists.

Over $80 \%$ of non-collision incidents involved passenger slips, trips and falls, and about $44 \%$ of these incidents occurred during boarding or alighting. Other slip, trip and fall incidents often occurred during the bus stop-servicing phases of acceleration and deceleration. The remaining non-collision incidents were associated with a wide variety of circumstances, the most common being struck by a door movement, or by a falling or moving object in the vehicle.

Each incident is reviewed by an internal committee (comprised of operators and safety managers) to determine whether it could have been prevented by following defined safe operating practices. As shown in Table 1, about one in five incidents was subsequently judged to have been preventable. However, preventability varies considerably across the incident typology. At the upper end, over 66\% the incidents involving a bus running into another vehicle and nearly $59 \%$ of collisions with a fixed object were judged to have been preventable. Alternatively, only one in 25 non-collision incidents was judged to have been preventable, with slips, trips and falls during boarding or alighting being the least preventable. 
Table 1 Breakdown of TriMet Bus Safety Incidents, 2006-2009

$$
(\mathrm{n}=4,631)
$$

\begin{tabular}{|c|c|c|}
\hline Incident Type & Percent of Total & Preventable $(\%)$ \\
\hline Collisions & $56.8 \%$ & $30.7 \%$ \\
\hline - With Motor Vehicles & 27.3 & 29.6 \\
\hline - Vehicle into Bus & 17.4 & 9.5 \\
\hline - Bus into Vehicle & 9.9 & 66.2 \\
\hline - With Fixed Objects & 5.5 & 58.6 \\
\hline - Mirror Strikes & 21.9 & 25.6 \\
\hline - With Pedestrians & 1.1 & 32.7 \\
\hline - With Bicyclists & 1.0 & 19.6 \\
\hline Non-Collisions & 43.2 & 4.1 \\
\hline - Slips, Trips \& Falls & 35.2 & 4.0 \\
\hline - Related to Boarding \& Alighting & 15.4 & 2.4 \\
\hline - Other Slips, Trips \& Falls & 19.9 & 5.2 \\
\hline - Other Non-Collision & 8.0 & 4.7 \\
\hline Overall & 100.0 & 19.2 \\
\hline
\end{tabular}

Two general concerns of transit operations management relate to whether discernable safety-incident patterns are evident over the course of daily operations or over the course of operators' shifts. These patterns are shown for collision and non-collision incidents in Figures 1 and 2. In each figure, exposure is controlled by operator hours. In Figure 1, the rate of collisions is more elevated during the morning and (particularly) evening peak periods, when higher traffic volumes contribute to greater collision risk. In contrast, the non-collision rate gradually increases from a low at 3 a.m. to a peak at 5 p.m., possibly reflecting growing fatigue among passengers commuting to and from work.

In Figure 2, the collision rate generally declines over the first eight shift hours. The collision rate then turns upward for those operators transitioning into overtime work, with the peak occurring in the $11^{\text {th }}$ work hour. The relatively few operators working beyond 11 hours are typically providing a voluntary fill of open work. Overall, the collision rate pattern over shift hours is consistent with concerns expressed in the literature on operator fatigue. The rate of non-collision incidents is fairly stable over the first eight shift hours, but also turns upward with overtime. Thus it appears that overtime-related operator fatigue is contributing to greater collision and non-collision risk. 
Figure 1 Collision and Non-Collision Rates By Time of Day

(Incidents per 10,000 Operator Hours)

שCollision $\underline{\underline{\underline{\underline{\underline{\underline{E}}}}} \text { Non-Collision }}$

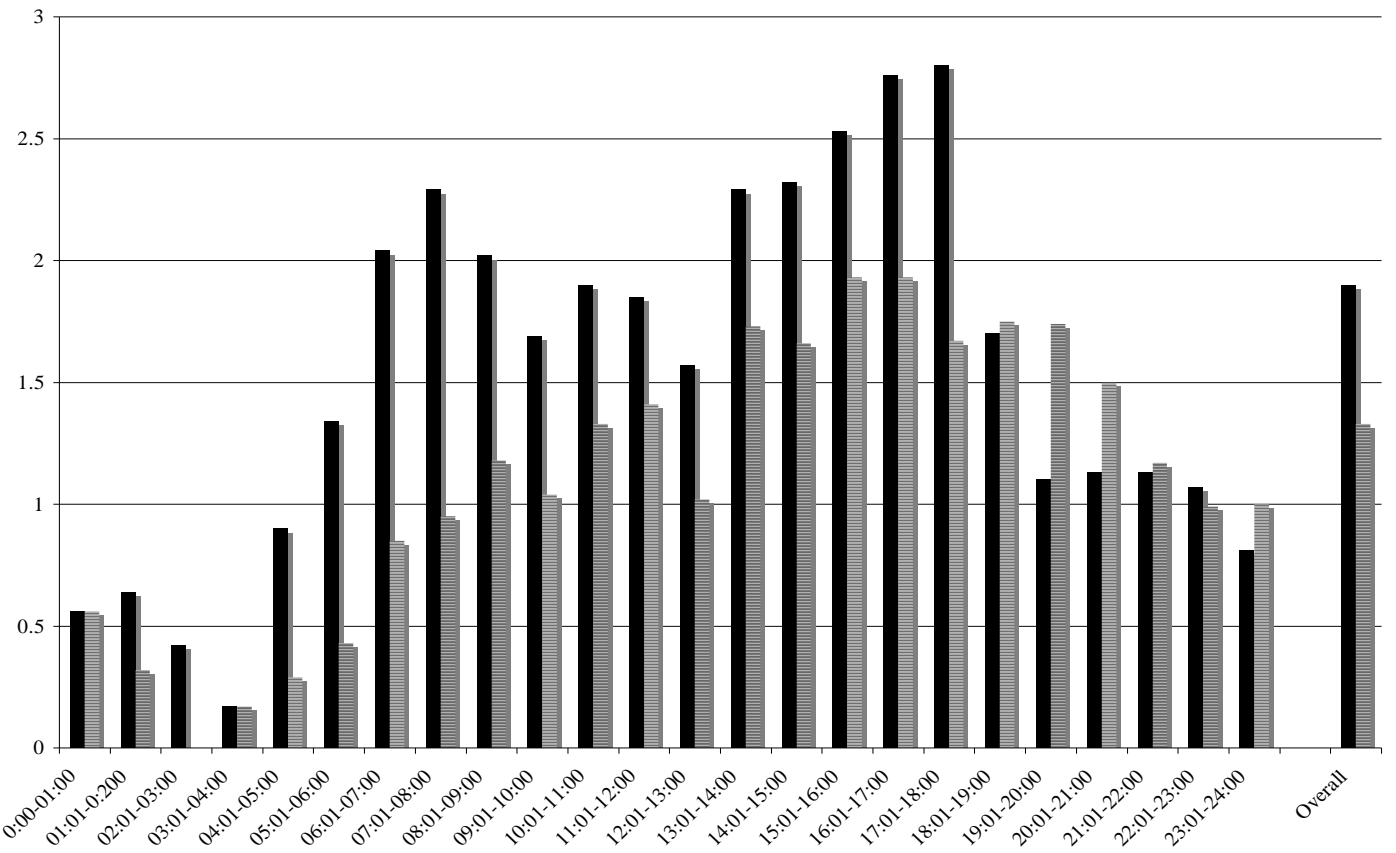

Figure 2 Collision and Non-Collision Rates By Shift Hour (Incidents per 10,000 Operator Hours)

- Collision 镸 Non-Collision

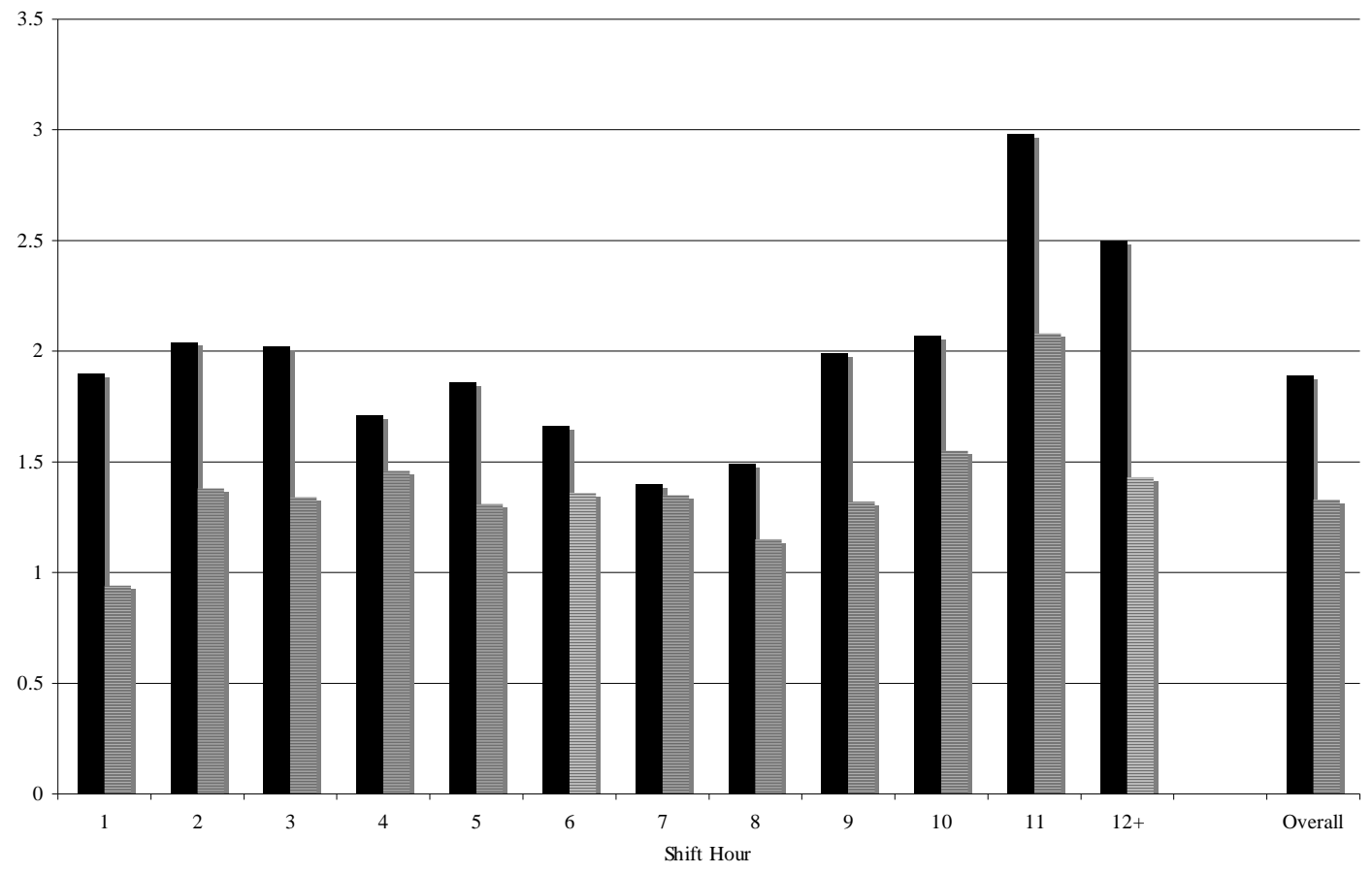




\subsection{OPERATOR SAFETY MODEL}

An operator-level model is described below, relating safety-incident frequencies to demographic characteristics and employment status, assigned work, service-delivery performance, and customer feedback on performance. The unit of observation is defined as an operator signup, a three-month period (also called a "pick" or a "booking") for which regular-duty operators select work assignments developed by the Scheduling Office using scheduling and run-cutting software. The model spans 12 signups and includes 1,502 operators. The number of operator-signup observations totals 13,796, given that some operators are not observed in every signup (as a result of retirements, quits, new hires, and transfers to or from other transit-mode assignments). A count estimation approach is employed, considering that incidents are measured as nonnegative integers and that the frequency distribution of incidents is skewed toward zero.

The safety-incidence model takes the following general form:

$$
\text { Incdts }_{\mathrm{ijt}}=\mathrm{f}\left(\text { Dem.jt }_{\cdot \mathrm{t}}, \text { Empl.jt }_{\cdot \mathrm{t}}, \text { Work }_{\mathrm{jt}}, \text { Perf. }_{\text {.jt }}, \text { Cust.jt }_{\mathrm{jt}}\right) \text {, where }
$$

Incdts $_{\mathrm{ijt}}=$ the number of safety incidents of type i involving operator $\mathrm{j}$ 's bus that occurred during signup t;

Dem.jt $_{\cdot j}=$ a vector of operator j's demographic characteristics on the first day of signup t;

Empl $_{. j t}=$ a vector of operator $j$ 's employment status characteristics on the first day of signup t;

Work $_{\mathrm{jt}}=\mathrm{a}$ vector of operator $\mathrm{j}$ 's assigned work characteristics during signup $\mathrm{t}$;

Perf $_{. j t}=$ a vector of operator j's service delivery and performance indicators during signup t;

Cust. $_{. j t}=$ a vector of customer commendations and complaints referencing operator $\mathrm{j}$ received during signup $\mathrm{t}$.

The model distinguishes between collision and non-collision events. A more detailed representation of incident types would provide greater specificity, but this would also result in a larger share of zero event observations, the implications of which will be discussed later.

Variables covering demographic characteristics include operators' age, sex, race, and ethnicity. Employment status is represented by seniority (years of service), as well as a dummy variable identifying operators on probation (which applies during the first six months in service).

The assigned work of regular operators is nominally fixed throughout a signup with respect to shift time, total hours of work, daily span of work, route, and bus type. However, regular operators can temporarily trade out of their assignments. The assignments of other types of operators can vary, in some instances across all work 
characteristics. For example, the assignments of extraboard operators can vary daily in filling work that opens as a result of regular-duty operator absences. A less variable example is the work of regular-relief operators, who fill open work blocks of operators on leave (e.g., vacations, jury duty). Less variable yet is the assigned work of regular-duty operators with assignments covering multiple (i.e., interlined) routes. Finally, operators can volunteer to work overtime or on their scheduled days off, if needed.

The complexity and impact of the work actually performed by operators are represented by a variety of variables. First, total hours worked is included to represent risk exposure. Second, hours of work performed on weekends is included to distinguish expected lower safety risk associated with lower traffic volume on those days. Third, operator fatigue is represented by a) variables for average daily work span, work span coefficient of variation, and a dummy for operators with split shifts; b) short duration (three consecutive days or less) absence hours associated with sick leaves, unexcused absences, and leaves related to a serious medical condition, as defined under the Family and Medical Leave Act (USDOL, 2007); and c) dummy variables identifying operators who signed into compressed three-day/30 hour during three of the study's signups and fourday/40 hour work weeks during one signup. Fourth, the number of distinct pieces of work performed during a signup is measured for each operator. Fifth, dummy variables are included to distinguish work dispatched from two of TriMet's three bus garages. One garage (Merlo) provides service to the metro area's west side, while the other (Powell) serves the east side. Sixth, differentiation of the route-operating environment is represented by a series of dummy variables corresponding to TriMet's route typology: secondary radial, crosstown, feeder, and peak express, with frequent service radial excluded. Given the variability of work actually performed, these dummies were coded one when the majority of an operator's work was performed on a given route type. Seventh, time of day is represented by dummy variables identifying whether a majority of an operator's runs concluded between 4-7 p.m. or after 7 p.m. Lastly, equipment is distinguish by dummy variables identifying whether a majority of an operator's runs utilized a low-floor, older (over 15 years), or smaller-than-standard-size bus.

Operators' service-delivery performance is represented by a variety of variables derived from archived ITS data. For each operator, the proportion of early and late departures from route time points is included. The operator's mean maximum speed between time points is similarly measured in relation to peer operators serving the same route(s) at the same time(s). Passenger boardings and lift-usage counts are measured per revenue hour. The lift-usage variable is included to proxy service to passengers with disabilities, but likely overrepresents passengers with greater mobility impairments. Actual average layover time is measured in proportion to platform-service time.

Archived MDT event variables include counts of operator-keyed security response requests and events involving an evasive action (e.g., "hard stops").

Customer information variables include the number of complaints related to an operator's unprofessional conduct, unsafe operation of the bus, or problems associated with timely service delivery (e.g., missed stops, pass-ups and early departures). ${ }^{1}$ Customer 
commendations of operators distinguish between those related to stop announcements and those for all other reasons. Lastly, the number of events involving questions related to an operator's "fitness for duty" is measured. The sources of this information include customers, field supervisors, and others.

Temporal effects are represented by both seasonal and annual dummy variables.

Defining the time span of the observations involves trade-offs between the need to account for "zero-inflation" issues related to the incidence of collision and non-collision events, and the need to minimize measurement error and heterogeneity in the variables representing operators' work and risk exposure (Lord et al., 2005; 2007). Regarding zero-inflation concerns, a three-month signup is a short time span for modeling collision and non-collision events. Although lengthening the time span would reduce the share of zero-event observations (totaling $83.7 \%$ for collisions and $88.5 \%$ for non-collisions at the signup level), it would exacerbate other problems. First, as discussed earlier, operators' work is organized by signups. Within this time frame, their work can be reasonably represented by the model's variables. Over a longer time frame, the representativeness of these variables erodes, with consequences manifested in greater measurement error and risk heterogeneity.

Regarding treatments for zero-inflation, there is no basis (in either the literature on transit safety research or in the perspectives of transit operations managers) for positing that a "virtually safe" state ever exists among bus operators and their assigned work. Evidence of such is necessary to justify application of zero-inflation estimators. Thus, zeroinflation estimators will not be employed. 


\subsection{ESTIMATION AND RESULTS}

The collision and non-collision models were estimated as Poisson and Negative Binomial regressions in SAS. Tests for overdispersion (Washington et al., 2003) were significant for both models, and Negative Binomial estimation was thus employed. Parameter estimates are presented in Table 2. Given that the parameter values are not directly interpretable, the associated elasticities (for continuous variables) and pseudo-elasticities (for dummy variables) are reported for estimates that are significant beyond the .05 level. For continuous variables, the elasticities represent the proportionate change in the expected frequency of collision or non-collision events with respect to a proportionate change in a given variable. For dummy variables, the pseudo-elasticities represent the proportionate change in expected incident frequency relative to the reference (i.e., omitted) category (Washington et al., 2003).

Table 2 Parameter Estimates of the Collision and Non-Collision Models

\begin{tabular}{|c|c|c|c|c|c|}
\hline \multirow[b]{2}{*}{ Variable } & \multirow[b]{2}{*}{$\begin{array}{c}\text { Mean } \\
\text { (Std. Dev.) }\end{array}$} & \multicolumn{2}{|c|}{ Collision Events } & \multicolumn{2}{|c|}{ Non-Collision Events } \\
\hline & & $\begin{array}{l}\text { Par. Estimate } \\
\text { (Std. Error) }\end{array}$ & Elasticity & $\begin{array}{l}\text { Par. Estimate } \\
\text { (Std. Error) }\end{array}$ & Elasticity \\
\hline \multicolumn{6}{|l|}{ Dependent Variables } \\
\hline Collision Events & $\begin{array}{l}.184 \\
(.443)\end{array}$ & -- & -- & -- & -- \\
\hline Non-Collision Events & $\begin{array}{l}.132 \\
(.398)\end{array}$ & -- & -- & -- & -- \\
\hline \multicolumn{6}{|l|}{ Independent Variables } \\
\hline \multicolumn{6}{|c|}{ Operator Characteristics } \\
\hline Age & $\begin{array}{c}49.4 \\
(10.9)\end{array}$ & $\begin{array}{l}.020 \\
(.008)\end{array}$ & \multirow{2}{*}{.096} & $\begin{array}{l}-.008 \\
(.003)\end{array}$ & -.390 \\
\hline $\mathrm{Age}^{2}$ & $\begin{array}{c}2560.3 \\
(953.5)\end{array}$ & $\begin{array}{c}.0003 \\
(.0001)\end{array}$ & & - & -- \\
\hline Years Experience & $\begin{array}{c}10.2 \\
(8.4)\end{array}$ & $\begin{array}{l}-.048 \\
(.011) \\
\end{array}$ & \multirow{2}{*}{-.032} & $\begin{array}{l}-.023 \\
(.006) \\
\end{array}$ & -.238 \\
\hline Years Experience $^{2}$ & $\begin{array}{c}175.12 \\
(253.53)\end{array}$ & $\begin{array}{l}.0008 \\
(.0003)\end{array}$ & & -- & -- \\
\hline Probationary Status & $\begin{array}{l}.074 \\
(.262)\end{array}$ & $\begin{array}{l}.212 \\
(.094)\end{array}$ & .191 & $\begin{array}{l}.441 \\
(.114)\end{array}$ & .356 \\
\hline Female & $\begin{array}{c}.308 \\
(.462) \\
\end{array}$ & $\begin{array}{l}.030 \\
(.049) \\
\end{array}$ & -- & $\begin{array}{l}.154 \\
(.063) \\
\end{array}$ & .143 \\
\hline African-American & $\begin{array}{l}.140 \\
(.347)\end{array}$ & $\begin{array}{l}-.073 \\
(.063)\end{array}$ & -- & $\begin{array}{l}-.126 \\
(.083)\end{array}$ & - \\
\hline Asian/Pacific Islander & $\begin{array}{c}.035 \\
(.184) \\
\end{array}$ & $\begin{array}{l}-.152 \\
(.123) \\
\end{array}$ & -- & $\begin{array}{l}-.053 \\
(.164) \\
\end{array}$ & -- \\
\hline Hispanic & $\begin{array}{c}.037 \\
(.190) \\
\end{array}$ & $\begin{array}{c}.002 \\
(.108) \\
\end{array}$ & -- & $\begin{array}{l}.164 \\
(.129) \\
\end{array}$ & -- \\
\hline \multicolumn{6}{|c|}{ Assigned Work Characteristics } \\
\hline Unique Assignments & $\begin{array}{c}11.45 \\
(17.42)\end{array}$ & $\begin{array}{l}-.003 \\
(.002)\end{array}$ & -- & $\begin{array}{c}.003 \\
(.003)\end{array}$ & -- \\
\hline Split Shift & $\begin{array}{c}.30 \\
(.46) \\
\end{array}$ & $\begin{array}{c}.050 \\
(.087) \\
\end{array}$ & -- & $\begin{array}{c}.074 \\
(.114) \\
\end{array}$ & -- \\
\hline Total Hours Worked & $\begin{array}{c}383.5 \\
(125.8)\end{array}$ & $\begin{array}{l}.0016 \\
(.0003)\end{array}$ & .614 & $\begin{array}{l}.0022 \\
(.0004)\end{array}$ & .844 \\
\hline Weekend Hours & 75.7 & -.0014 & -.106 & -.0007 & -- \\
\hline
\end{tabular}




\begin{tabular}{|c|c|c|c|c|c|}
\hline & $(79.9)$ & $(.0004)$ & & $(.0005)$ & \\
\hline Average Daily Span & $\begin{array}{c}9.45 \\
(1.67) \\
\end{array}$ & \begin{tabular}{|l}
.056 \\
$(.021)$ \\
\end{tabular} & .528 & $\begin{array}{l}-.082 \\
(.028) \\
\end{array}$ & -.771 \\
\hline Daily Span CV & $\begin{array}{c}.14 \\
(.12) \\
\end{array}$ & $\begin{array}{c}.877 \\
(.305) \\
\end{array}$ & .123 & $\begin{array}{l}-.114 \\
(.418) \\
\end{array}$ & -- \\
\hline Three Day/30 Hour Week & $\begin{array}{c}.021 \\
(.145) \\
\end{array}$ & $\begin{array}{c}.242 \\
(.164) \\
\end{array}$ & -- & $\begin{array}{c}.651 \\
(.193) \\
\end{array}$ & .479 \\
\hline Four Day/40 Hour Week & $\begin{array}{r}.0003 \\
(.054) \\
\end{array}$ & $\begin{array}{l}-2.19 \\
(1.07) \\
\end{array}$ & -7.932 & $\begin{array}{c}.392 \\
(.438) \\
\end{array}$ & -- \\
\hline Short-Term Absence Hours & $\begin{array}{c}13.9 \\
(21.6) \\
\end{array}$ & $\begin{array}{c}.0038 \\
(.001) \\
\end{array}$ & .053 & $\begin{array}{c}.0004 \\
(.001) \\
\end{array}$ & -- \\
\hline Merlo Garage & $\begin{array}{c}.218 \\
(.413) \\
\end{array}$ & $\begin{array}{l}.1991 \\
(.080) \\
\end{array}$ & -.220 & $\begin{array}{l}-.022 \\
(.106) \\
\end{array}$ & -- \\
\hline Powell Garage & $\begin{array}{c}.341 \\
(.474) \\
\end{array}$ & $\begin{array}{l}.0735 \\
(.053) \\
\end{array}$ & -- & $\begin{array}{l}.0002 \\
(.069) \\
\end{array}$ & -- \\
\hline Secondary Radial Route & $\begin{array}{r}.154 \\
(.36) \\
\end{array}$ & $\begin{array}{l}.011 \\
(.076) \\
\end{array}$ & -- & $\begin{array}{l}-.039 \\
(.108) \\
\end{array}$ & -- \\
\hline Crosstown Route & $\begin{array}{l}.238 \\
(.426) \\
\end{array}$ & $\begin{array}{l}.088 \\
(.058) \\
\end{array}$ & -- & $\begin{array}{l}-.171 \\
(.077) \\
\end{array}$ & -.186 \\
\hline Feeder Route & $\begin{array}{l}.059 \\
(.235) \\
\end{array}$ & $\begin{array}{l}.110 \\
(.152) \\
\end{array}$ & -- & $\begin{array}{c}.065 \\
(.228) \\
\end{array}$ & -- \\
\hline Peak Express Hours & $\begin{array}{l}.027 \\
(.162)\end{array}$ & $\begin{array}{c}.051 \\
(.156)\end{array}$ & -- & $\begin{array}{l}-.394 \\
(.304)\end{array}$ & -- \\
\hline Shift Ends 4-7 p.m. & $\begin{array}{l}.501 \\
(.500)\end{array}$ & $\begin{array}{l}-.126 \\
(.062)\end{array}$ & -.134 & $\begin{array}{c}.030 \\
(.084)\end{array}$ & -- \\
\hline Shift Ends After 7 p.m. & $\begin{array}{l}.189 \\
(.391) \\
\end{array}$ & $\begin{array}{l}.143 \\
(.075) \\
\end{array}$ & -- & $\begin{array}{c}.076 \\
(.098) \\
\end{array}$ & -- \\
\hline Low-Floor Bus & $\begin{array}{c}.657 \\
(.475)\end{array}$ & $\begin{array}{l}-.032 \\
(.078)\end{array}$ & -- & $\begin{array}{c}.032 \\
(.106)\end{array}$ & -- \\
\hline Old Bus & $\begin{array}{l}.234 \\
(.423) \\
\end{array}$ & $\begin{array}{l}-.145 \\
(.101) \\
\end{array}$ & -- & $\begin{array}{l}-.344 \\
(.146) \\
\end{array}$ & -.411 \\
\hline Small Bus & $\begin{array}{l}.046 \\
(.21) \\
\end{array}$ & $\begin{array}{l}-.142 \\
(.167) \\
\end{array}$ & -- & $\begin{array}{l}-.236 \\
(.277)\end{array}$ & -- \\
\hline \multicolumn{6}{|l|}{ Service Performance Chars. } \\
\hline Boardings per Revenue Hour & $\begin{array}{c}43.3 \\
(10.3) \\
\end{array}$ & $\begin{array}{l}.001 \\
(.003) \\
\end{array}$ & -- & $\begin{array}{c}.005 \\
(.004) \\
\end{array}$ & -- \\
\hline Lifts per Hour & $\begin{array}{c}.29 \\
(.15) \\
\end{array}$ & $\begin{array}{c}.484 \\
(.184) \\
\end{array}$ & .139 & $\begin{array}{c}.768 \\
(.242) \\
\end{array}$ & .220 \\
\hline Avg. Max. Speed - Peer Speed & $\begin{array}{c}.05 \\
(1.50) \\
\end{array}$ & $\begin{array}{c}.001 \\
(.015) \\
\end{array}$ & -- & $\begin{array}{c}.032 \\
(.022) \\
\end{array}$ & -- \\
\hline Proportion Late Departs & $\begin{array}{l}.149 \\
(.103)\end{array}$ & $\begin{array}{c}.810 \\
(.238) \\
\end{array}$ & .121 & $\begin{array}{l}1.097 \\
(.30) \\
\end{array}$ & .163 \\
\hline Proportion Early Departs & $\begin{array}{l}.054 \\
(.059)\end{array}$ & $\begin{array}{l}1.213 \\
(.383)\end{array}$ & .066 & $\begin{array}{l}-.657 \\
(.580)\end{array}$ & -- \\
\hline Layover Proportion & $\begin{array}{c}.255 \\
(.310)\end{array}$ & $\begin{array}{l}-.047 \\
(.096)\end{array}$ & -- & $\begin{array}{l}-.226 \\
(.279)\end{array}$ & -- \\
\hline Security Requests & $\begin{array}{c}.50 \\
(.98) \\
\end{array}$ & $\begin{array}{c}.027 \\
(.021)\end{array}$ & -- & $\begin{array}{c}.095 \\
(.023)\end{array}$ & .047 \\
\hline Evasive-Action Events & $\begin{array}{c}.02 \\
(.16) \\
\end{array}$ & $\begin{array}{c}.072 \\
(.115) \\
\end{array}$ & -- & $\begin{array}{c}.938 \\
(.074) \\
\end{array}$ & .023 \\
\hline \multicolumn{6}{|l|}{ Customer Service Information } \\
\hline Unsafe Operation & $\begin{array}{c}.21 \\
(.52)\end{array}$ & $\begin{array}{c}.096 \\
(.038)\end{array}$ & .020 & $\begin{array}{c}.097 \\
(.049)\end{array}$ & .020 \\
\hline Unprofessional Treatment & $\begin{array}{c}.39 \\
(.81) \\
\end{array}$ & $\begin{array}{c}.045 \\
(.025) \\
\end{array}$ & -- & $\begin{array}{c}.104 \\
(.030) \\
\end{array}$ & .041 \\
\hline Fit for Duty & $\begin{array}{l}.007 \\
(.084)\end{array}$ & $\begin{array}{l}.249 \\
(.218)\end{array}$ & -- & $\begin{array}{c}.297 \\
(.294)\end{array}$ & -- \\
\hline Service Delivery Problem & $\begin{array}{c}.11 \\
(.41) \\
\end{array}$ & $\begin{array}{c}.010 \\
(.049) \\
\end{array}$ & -- & $\begin{array}{c}.029 \\
(.068) \\
\end{array}$ & -- \\
\hline Commendation: Calls Stops & $\begin{array}{c}.69 \\
(1.38) \\
\end{array}$ & $\begin{array}{l}.009 \\
(.015) \\
\end{array}$ & -- & $\begin{array}{c}.021 \\
(.019) \\
\end{array}$ & -- \\
\hline
\end{tabular}




\begin{tabular}{|c|c|c|c|c|c|}
\hline Commendation: Other & $\begin{array}{c}.30 \\
(.70)\end{array}$ & $\begin{array}{c}.061 \\
(.025)\end{array}$ & .018 & $\begin{array}{c}.025 \\
(.037)\end{array}$ & -- \\
\hline \multicolumn{6}{|c|}{ Temporal Characteristics } \\
\hline Fall Signup & $\begin{array}{c}.252 \\
(.434) \\
\end{array}$ & $\begin{array}{l}.088 \\
(.060) \\
\end{array}$ & -- & $\begin{array}{c}.089 \\
(.079) \\
\end{array}$ & $\overline{--}$ \\
\hline Spring Signup & $\begin{array}{c}.253 \\
(.435) \\
\end{array}$ & $\begin{array}{c}.058 \\
(.066) \\
\end{array}$ & -- & $\begin{array}{l}.031 \\
(.093)\end{array}$ & -- \\
\hline Summer Signup & $\begin{array}{c}.170 \\
(.376)\end{array}$ & $\begin{array}{l}-.019 \\
(.067)\end{array}$ & -- & $\begin{array}{c}.056 \\
(.090)\end{array}$ & -- \\
\hline 2007 & $\begin{array}{c}.414 \\
(.493)\end{array}$ & $\begin{array}{c}.154 \\
(.076)\end{array}$ & .142 & $\begin{array}{c}.030 \\
(.100)\end{array}$ & -- \\
\hline 2008 & $\begin{array}{c}.345 \\
(.476) \\
\end{array}$ & $\begin{array}{c}.044 \\
(.082) \\
\end{array}$ & -- & $\begin{array}{l}.135 \\
(.107) \\
\end{array}$ & -- \\
\hline 2009 & $\begin{array}{c}.086 \\
(.280) \\
\end{array}$ & $\begin{array}{l}-119 \\
(.118) \\
\end{array}$ & - & $\begin{array}{l}.052 \\
(.158) \\
\end{array}$ & -- \\
\hline Intercept & -- & $\begin{array}{r}-2.69 \\
(.32) \\
\end{array}$ & -- & $\begin{array}{c}-2.32 \\
(.38) \\
\end{array}$ & -- \\
\hline$\rho^{2}$ & & $.031 *$ & & $.073 *$ & \\
\hline Sample Size & 13,796 & 13,796 & & 13,796 & \\
\hline
\end{tabular}

$* \rho^{2}=1-\left(\mathrm{LL}_{\beta} / \mathrm{LL}_{0}\right)$, where $\mathrm{LL}_{\beta}$ is the log likelihood value at convergence for the estimated parameters, and $\mathrm{LL}_{0}$ is the $\log$ likelihood value with all parameters set at zero.

\section{Operator Characteristics}

The parameter estimates indicate that operators' incident frequencies are related to both experience and age. For those operators who are new to the job and still on probation, the expected frequency of collision and non-collision incidents is more than $19 \%$ and $35 \%$ greater, respectively, than the corresponding frequencies for regular operators. Beyond probation, the estimated effect of experience on collisions is negative and diminishing, reaching zero at 30.0 years of service and turning positive beyond that point. The negative collision elasticity reported in Table 2 reflects the fact that average operator experience (10.2 years) is well short of the 30-year transition point. The effect of experience on non-collision frequency is estimated to be linear and negative, with the expected incident frequency of an operator with, for example, 20 years of service being nearly $24 \%$ lower than that of an operator with 10 years of service.

Like experience, the effect of age on expected collision frequency is negative and diminishing. In contrast, however, the negative-to-positive transition point is reached at age 33.3, well below of the sample average of 49.4 years. Thus the age elasticity for the operator sample is positive. The age elasticity for non-collisions is negative and is based on a linear parameter estimate.

The parameter estimates indicate that there are no significant distinctions in the expected frequency of collision or non-collision incidents that can be related to operators' race or ethnicity. In contrast, the expected frequency of non-collision incidents for female operators is over $14 \%$ greater than their male counterparts. There is no clear interpretation of this finding, although it should be noted that incidents are self-reported by operators. Collisions (where no gender distinctions are found) leave tangible 
evidence, making non-reporting less likely. One can thus speculate that female operators are either more likely to report non-collision incidents or that passengers who experience non-collision incidents are more likely to acknowledge them to a female than to a male operator.

\section{Assigned Work Characteristics}

An operator's total hours of work during a signup represents an indicator of collision and non-collision risk exposure. A test of the hypothesis that the corresponding elasticities equal one was rejected for the collision elasticity and not rejected for the non-collision elasticity. The negative weekend hours elasticity suggests that collision risk diminishes on days when regional traffic volumes are lower and congestion is less pronounced. Reductions in weekend risk do extend to non-collision incidents, however.

Holding total hours constant, the expected frequencies of collision and non-collision incidents are influenced by the average daily span of hours as well as span variability. For collisions, an increase in work span from, say, 10 to 11 hours is estimated to result in a 5.3\% increase in collision frequency. For span variability, a 10\% increase in the span's coefficient of variation is estimated to result in a $1.2 \%$ increase in collision frequency. The former finding is most relevant to operators on split shifts, and it suggests that increases in the amount of time separating shifts would contribute to greater collision frequency. It also suggests that compressed workweeks, with their approximate $25 \%$ increase in daily span for full-time operators, would also result in greater collision frequency. The latter finding is most relevant to operators who work the extraboard as well as operators who engage in frequent trades of their assigned work. Both circumstances are associated with greater span variation.

Independent of span-related effects on incident frequencies, the parameter estimate for the dummy variable identifying operators with split shifts is not significant. Dummy variables were also specified to identify a small number of operators with compressed workweeks. In this case, the findings are mixed, with part-time operators on three-day, 30-hour weeks estimated to experience higher non-collision frequencies, and operators on four-day, 40-hour weeks estimated to experience lower collision frequencies.

Variations in short-duration absence hours are estimated to be positively associated with expected collision frequency. Short-duration absences account for about half of total time loss among operators at TriMet. Focusing on the short-duration component of operator time loss lessens the prospect of simultaneity, wherein it would be necessary to consider operator absences as a contributor to safety incidents as well as a consequence. While the estimated short-duration absence elasticity can be interpreted as a contributor to collision frequency, it is still not possible to distinguish between operators' health and their job satisfaction as the basis of the contribution. Lastly, among the various workhour effects examined, an unanticipated finding is the estimated reduction in the expected frequency of non-collision incidents associated with increases in average daily work span. 
Shift period is represented by several dummy variables identifying the time of day when an operator's runs conclude. The expected collision frequencies of operators whose runs conclude between 4-7:00 p.m. (accounting for about half of all runs) are 13.4\% lower than the expected frequencies of operators whose runs conclude earlier or later than this period. Among the three garages, the expected collision frequency of buses dispatched from Merlo is estimated to be $22 \%$ below Central (the reference garage), while the safety performance of buses dispatched from Powell does not differ significantly.

Variations in operating conditions are represented by the route typology dummy variables. It was expected that collision frequencies would be greater on frequent service radials (the reference category), given that traffic volumes are generally higher along these routes and on-street parking is more prevalent. However, with the exception of lower non-collision incidents estimated for crosstowns, the collision and non-collision elasticities among the alternative route types do not differ significantly from frequent service radials.

With respect to equipment, the expected non-collision frequencies among low-floor buses were not found to be significantly lower than for other bus types, contrary to what has been observed elsewhere. A possible explanation for this finding is the practice at TriMet of assigning its low-floor vehicles to the most heavily patronized routes, which would contribute to a confounding of the bus-type and passenger-boarding variables in the model. Also, a nominally unusual finding is that the expected non-collision frequencies among buses older than 15 years is estimated to be about $40 \%$ below that of newer vehicles. A possible interpretation of this finding relates to TriMet's practice of assigning older vehicles to morning and evening peak period tripper service, when its usage profile shifts toward younger and presumably fitter customer cohorts.

\section{Service Performance Characteristics}

Independent of the effects of risk exposure associated with total hours worked, it was expected that non-collision incident frequencies would be positively related to passenger boardings. This is not found to be the case. However, both collision and non-collision frequencies are found to be positively related to lift movements. The latter effect indicates that passengers with mobility impairments face distinct safety risks associated with lift malfunctions and on-board securement (NHTSA, 1997). Interpretation of the collision effect would be very speculative. One possibility is that the time and attention that operators devote to serving passengers with disabilities conflicts with the time and attention needed to safely operate the vehicle. For example, a bus lift operation requires about 60 seconds of additional dwell time (Dueker et al., 2004), contributing to the likelihood of running late and serving as an incentive to compromise safety in returning to the schedule.

Independently, the frequency of collision and non-collision incidents is estimated to be positively related to the failure to maintain a schedule. Both collision and non-collision frequencies are estimated to increase with the proportion of late (by more than five minutes) departures from time points. Possible reasons for this finding may be somewhat complicated. While speeding might be suspected, it is already controlled for in the model 
and is not found to be significant. Alternative options for schedule recovery would be to cut deceleration, dwell, or acceleration times, each of which is known to contribute to greater risk of collision and non-collision events. Early (by more than one minute) departures from time points are much less common and are entirely avoidable. One motivation for running early is that it adds to the amount of layover time. The positive effects of running early on collision frequency, while significant, are about half the magnitude of the effects associated with running late.

While the literature has identified insufficient layover time as a contributor to operator fatigue and safety risk, the model's collision and non-collision parameter estimates for the share of platform time devoted to layover are not significant. By agreement, TriMet run cuts must assure a minimum of 80 minutes of layover and break time in an eight-hour shift, which represents about $17 \%$ of platform time. As Table 2 shows, the actual run cuts implemented during the study period yielded a layover share that exceeded $25 \%$. Thus, in practice, it appears that the layovers actually provided were sufficient to ensure safety.

Among the event messages transmitted by operators to dispatchers are incidents in which they needed to take evasive action (e.g., "hard stops"), as well as incidents requiring a response by security personnel. The estimated effect of both types of events on expected non-collision frequencies, while significant, is fairly small. Taking evasive action itself may be a contributor to an on-board safety incident. In contrast, a security request may occur as an outcome of an on-board safety incident, particularly when the consumption of alcohol or other substances is involved.

\section{Customer Service Information}

The expected frequency of both collision and non-collision incidents is estimated to be positively related to customer complaints addressing unsafe operation of the vehicle. In some instances, the safety incident itself may serve as a motivation for lodging a complaint. Customer complaints of unprofessional treatment by operators are also estimated to be positively related to the expected frequency of non-collision incidents.

Customer commendations of operators (unrelated to stop announcements) are estimated to be positively associated with expected collision frequencies. While this finding was not anticipated, it is not inconsistent with the literature's depiction of operators' conflicting customer service and safe operation responsibilities. For example, in their study of job performance and personality traits among nearly 900 bus operators sampled from multiple U.S. properties, Jacobs et al. (1996) found that operators with the fewest accidents tended to be more low-key, even-tempered and conscientious about their work. Such personality characteristics may be less likely to draw commendations from customers. This interpretation is weakly substantiated by the present study's customer information data, where general commendations are correlated with both unsafe operation $(\mathrm{r}=.025)$ and with unprofessional treatment $(\mathrm{r}=.039)$ complaints. Thus, more sociable operators may draw more commendations and more complaints, and may also be less conscientious about safety. 


\section{Temporal Characteristics}

There is evidence of snow and ice-related spikes in safety incidents during two of the study period's Winter signups, with each less than a week in duration. Also, in contrast to Summer and Fall, the Winter and Spring signups are fairly consistently subject to variable light rainfall. However, none of the signup dummy variables was found to be significant, suggesting that seasonal variations in the Portland region's weather have no discernable consequences in the frequency of collision or non-collision incidents.

Among the annual dummy variables, only the expected frequency of collision incidents in 2007, estimated to be more than $14 \%$ above the 2006 frequency, was significant. The economic downturn in the Portland region after 2007 may have had an effect on safety. Between a January 2008 peak and August 2009, regional employment fell 6.3\% and total regional employment returned to early 2001 levels (Vander Vliet, 2009). Thus, some easing of traffic-related risk exposure was likely to have occurred during that period. 


\subsection{CONCLUSIONS}

This report has examined collision and non-collision incidents associated with bus operations at TriMet. Empirical analysis encompassed over 4,600 incidents that occurred over a three-year period. Regression analysis has identified a variety of factors associated with the frequency of collision and non-collision incidents, including operator demographics, employment status, characteristics of assigned work, performance in delivering service, and information provided by customers about their riding experiences. Principal findings are summarized below, and their management or policy implications are discussed.

First, beyond the initial probationary period of employment, the regression results indicate that there are diminishing marginal safety returns associated with both operator age and length of service, where the collision frequency elasticities become positive at age 30 and when length of service reaches 33 years. Regarding the age effect, traffic safety researchers have long recognized that drivers' motor and cognitive performance diminish with age, although the transition point estimated in this study occurs when bus operators are still relatively young.

This finding may not surprise those who have studied the health and wellness of transit operators. However, health and wellness research in the transit industry has tended to focus on such outcomes as health expenses, workers' compensation costs, absenteeism costs, and operator turnover costs (Davis, 2004). As this study's findings indicate, safety outcomes and costs should also be a relevant concern associated with the aging of operators. The diminishing marginal safety returns to operator length of service point to a need for more emphasis on regular refresher training, a practice that an industry survey by Moffat et al. (2001) found is utilized by only 36\% of transit properties.

Second, operator absenteeism has been a long-standing focus of an industry concerned with containing health expenses and labor costs, as well as reducing labor turnover. Beyond these concerns, this study's findings indicate that absenteeism also contributes both directly and indirectly to safety outcomes and costs: directly in the positive association found between an operator's absence hours and his expected collision frequency, and indirectly through the absence-driven demand for extraboard replacement operators, whose more varied daily work spans are estimated to contribute to greater collision frequency.

Third, the transit safety literature has identified operator fatigue as a serious concern, and this study's findings offer support for this concern in several respects. Generally, collision and non-collision risk is greater during overtime shift hours. Also, when controlling for hours worked, increasing the daily span of hours - as is the case for splitshift operators - is estimated to increase the expected frequency of collisions. Fatiguerelated concerns associated with the disruptive effects of variable work assignments are 
also supported by the positive link estimated between work-span variability and expected collision frequency. Thus, expected labor cost savings that motivate the use of such work assignments are at least partially undermined by higher safety costs.

Fourth, operator surveys reveal that pressures to maintain a schedule are a key source of occupational stress. This study has found that running late is a significant contributor to the expected frequency of both collision and non-collision incidents. With the advent of AVL systems, schedule writers now have access to abundant running-time information, reducing the likelihood that running late is a consequence of a poorly written schedule. However, schedules are written to be compatible with the abilities of a "typical" operator (Levinson, 1991). The "variance" of abilities in relation to the typical operator means that some operators will face greater difficulty maintaining a schedule on a given route. Hypothetically, it would thus be beneficial to assign work so that such variance is minimized. However, it has been a time-honored (and bargained) right of operators to select work on the basis of seniority, which may or may not be compatible with a "minimum variance" alternative.

Fifth, related to operators' schedule maintenance pressures, additional dwell time associated with lift operations can be directly factored into schedules when the frequency of lift operations is regular and predictable. When lift usage is sporadic, it is commonly treated as another contributor to random delay, and is addressed indirectly in the recovery time that is built into a schedule. While the positive association between lift usage and expected collision frequency estimated in this study can be interpreted as a scheduling problem, more detailed analysis of lift activity at the route and trip levels would be needed to determine how the problem should be addressed in the schedule-writing process.

In addition, this study has found a positive association between lift usage and the expected frequency of non-collision incidents, suggesting that customers with disabilities face a relatively greater safety risk. This finding underscores a need for continuing research on the design of lift and securement devices, as well as a need for continuing assessment of practices intended to ensure safe travel among this customer cohort.

Sixth, customer commendations and complaints serve as a valuable source of information that can be used to improve safety. While operators are often rightfully skeptical of the validity of pieces of customer information, this study has found that patterns of customer information offer important insights into operators' safety-related performance. The general message for transit management represented in this finding may be summarized as follows: listen to and follow up on pieces of customer information, and act on patterns of information.

Lastly, this study offers an example of the contribution that transit ITS data can make in achieving more comprehensive analysis and greater understanding of safety risks, especially when combined with other information commonly maintained in an agency's data warehouse. Surveys conducted by the U.S. Department of Transportation's (USDOT) Volpe Transportation Systems Center suggest that the transit industry has not 
yet extensively tapped the potential of archived ITS data with respect to safety analysis and planning. For example, a 2004 Volpe Center survey specifically queried transit agencies on their use of ITS data for accident analysis or prediction. Among properties responding from 80 metropolitan areas, only those from six indicated that they had used their data for this purpose (USDOT, 2009). Problems related to ITS data validation, data integration, staffing, and staff expertise in accessing and analyzing archived data have limited the ability of many transit properties to more fully realize the potential benefits of their new data resources in safety and other applications. The property serving as the focus of this study has been identified as one that has managed to overcome these problems (Strathman et al., 2008). Its experience offers lessons for others in promoting more effective utilization of transit ITS and other data resources. 


\subsection{FOOTNOTES}

1. The customer information variables are summarized from a more detailed typology of commendations and complaints. Customer complaints about operator cell-phone use are included in the detailed typology. The frequency of such complaints is insufficient to assess within the modeling framework employed in this study. A separate contingency analysis of the association between cell-phone complaints and collision involvement is presented in the Appendix. 


\subsection{REFERENCES}

American Public Transit Association. 2009. 2009 Public Transportation Fact Book, $60^{\text {th }}$ Edition. Washington, DC: Author.

Arnold, L. and L. Hartley. 2001. Policies and practices of transport companies that promote or hinder the management of driver fatigue. Transportation Research, Part $F, 4,1-17$.

Chang, H. and C. Yeh. 2005. Factors affecting the safety performance of bus companies: The experience of Taiwan bus deregulation. Safety Science, 43, 323-344.

Cheung, C., Shalaby, A., Persaud, B. and A. Hadayeghi. 2008. Models for safety analysis of road surface transit. Transportation Research Record: Journal of the Transportation Research Board, 2063, 168-175.

Davis, M. 2004. TCRP Synthesis 52: Transit Operator Health and Wellness Programs. Washington, DC: Transit Cooperative Research Program, Transportation Research Board of the National Academies.

Dorn, L. and af Wahlberg, A. 2008. Work-related road safety: An analysis based on U.K. bus driver performance. Risk Analysis, 28, 25-35.

Dueker, K., Kimpel, T. and J. Strathman. 2004. Determinants of bus dwell time. Journal of Public Transportation, 7, 21-40.

Evans, L. 2004. Traffic Safety. Bloomfield Hills, MI: Science Serving Society.

Federal Transit Administration. 2009a. 2007 Safety and Security Statistics. Washington, DC: author. Accessed at http://transit-safety.volpe.gov/data/SAMIS.asp on October 22, 2009.

Federal Transit Administration. 2009b. Industry accident and incident trend update. Bus Transit Safety and Security, Quarterly Newsletter. Winter Issue, 4-5.

Gertler, J., Popkin, S., Nelson, D. and K. O’Neil. 2002. TCRP Report 81: Toolbox for Transit Operator Fatigue. Washington, DC: Transit Cooperative Research Program, Transportation Research Board of the National Academies.

Hamed, M., Jaradat, A. and S. Easa. 1998. Analysis of commercial mini-bus accidents. Accident Analysis and Prevention, 30, 555-567.

Hundenski, R. 1992. Public transport passenger accidents: An analysis of the structural and functional characteristics of passenger and vehicle. Accident Analysis and Prevention, 24, 133-142. 
Jacobs, R., Conte, J., Day, D., Silva, J. and R. Harris. 1996. Selecting bus drivers: multiple predictors on validity, and multiple estimates of utility. Human Performance, 9, 199-217.

Jovanis, P., Schofer, J., Prevedouros, P. and K. Tsunokawa. 1991. Analysis of bus accidents: Empirical, methodological, and policy issues. Transportation Research Record: Journal of the Transportation Research Board, 1322, 17-28.

Kompier, M. and V. Di Martino. 1995. Review of bus drivers' occupational stress and stress prevention. Stress Medicine, 11, 253-262.

Krass, A. 1993. Impact of the U.S. Motor Carrier Act of 1980 on road safety in California: An econometric policy evaluation. Logistics and Transportation Review, 29, 179-192.

Levinson, H. 1991. Synthesis of Transit Practice 15: Supervision Strategies for Improved Reliability of Bus Routes. Washington, DC: National Cooperative Transit Research and Development Program, Transportation Research Board of the National Academies.

Long, L. and J. Perry. 1985. Economic and occupational causes of transit operator absenteeism: A review of research. Transport Reviews, 5, 247-267.

Lord, D., Washington, S. and J. Ivan. 2007. Further notes on the application of zeroinflated models in highway safety. Accident Analysis and Prevention, 39, 53-57.

Lord, D., Washington, S. and J. Ivan. 2005. Poisson, Poisson-gamma and zero-inflated regression models of motor vehicle crashes: Balancing statistical fit and theory. Accident Analysis and Prevention, 37, 35-46.

Moffat, G., Ashton, A. and D. Blackburn. 2001. TCRP Synthesis 40: A Challenged Employment System: Hiring, Training, Performance Evaluation, and Retention of Bus Drivers. Washington, DC: Transit Cooperative Research Program, Transportation Research Board of the National Academies.

Monaco, K. and E. Williams. 2000. Assessing the determinants of safety in the trucking industry. Journal of Transportation and Statistics, 3, 69-80.

Morlok, E., Nitzberg, B. and L. Lai. 2004. Boarding and alighting injury experience with different station platform and car entranceway designs on US commuter railroads. Accident Analysis and Prevention, 36, 261-271.

National Highway Traffic Safety Administration. 1997. Research Note: Wheelchair Users Injuries and Death Associated With Motor Vehicle Related Incidents. Washington, DC: U.S. Department of Transportation. 
Pokorny, M., Blom, D., Van Leeuwen, P. and W. Van Nooten. 1987a. Shift sequences, duration of rest periods, and accident risk of bus drivers. Human Factors, 29, 73-81.

Pokorny, M., Blom, D. and P. Van Leeuwen. 1987b. Shifts, duration of work and accident risk of bus drivers. Ergonomics, 30, 61-88.

Ragland, D. Hundenski, R., Holman, B. and J. Fisher. 1992. Traffic volume and collisions involving transit and nontransit vehicles. Accident Analysis and Prevention, 24, 547-558.

Reason, J. 1997. Managing the Risks of Organizational Accidents. London: Ashgate Publishing.

Rodriguez, D., Rocha, M., Khattack, A. and M. Belzer. 2003. Effects of truck driver wages and working conditions on highway safety: Case study. Transportation Research Record: Journal of the Transportation Research Board, 1833, 95-102.

Strathman, J., Callas, S. and J. Broach. In press. Evaluation of short duration unscheduled absences among transit operators: TriMet case study. Transportation Research Record: Journal of the Transportation Research Board.

Strathman, J., Kimpel, T., Broach, J., Wachana, P., Coffel, K., Callas, S., Elliot, B. and R. Elmore-Yalch. 2008. TCRP Report 126: Leveraging ITS Data for Transit Market Research: A Practitioner's Guidebook. Washington, DC: Transit Cooperative Research Program, Transportation Research Board of the National Academies.

Technology and Management Systems. 2001. TCRP Report 66: Effective Practices to Reduce Bus Accidents. Washington, DC: Transit Cooperative Research Program, Transportation Research Board of the National Academies.

Texas Transportation Institute. 1996. TCRP Report 19: Guidelines for the Location and Design of Bus Stops. Washington, DC: Transit Cooperative Research Program, Transportation Research Board of the National Academies.

U.S. Department of Labor. 2007. Family and Medical Leave Act Regulations: A Report on the Department of Labor's Request for Information, 2007 Update. Wage and Hour Division, Employment Standards Administration, Author.

U.S. Department of Transportation. 2009. Intelligent Transportation Systems Deployment Statistics: Transit Management. Washington, DC: Research and Innovative Technology Administration, author. Accessed on September 2, 2009 at http://www.itsdeployment.its.dot.gov/SurveyOutline1.asp?SID=TM

Vander Vleit, A. 2009. Portland Metro Labor Trends. Salem, OR: Economic Research Division, Oregon Employment Department. October. 
Wahlberg, A. 2007. Effects of passengers on bus driver celeration behavior and incident prediction. Journal of Safety Research, 38, 9-15.

Wahlberg, A. and L. Dorn. 2009. Absence behavior as traffic crash predictor in bus drivers. Journal of Safety Research, 40, 197-201.

Washington, S., Karlaftis, M. and F. Mannering. 2003. Statistical and Econometric Methods for Transportation Data Analysis. Boca Raton, FL: Chapman \& Hall/CRC.

Winkleby, M., Ragland, D., Fisher, J. and S. Syme. 1988. Excess risk of sickness and disease in bus drivers: A review and synthesis of epidemiological studies. International Journal of Epidemiology, 17, 255-262.

Zegeer, C., Huang, H., Stutts, J. Rodgman, E., Hummer, J. and J. Fruin. 1993. Characteristics and Solutions Related to Bus Transit Accidents. Chapel Hill, NC: University of North Carolina Highway Safety Research Center. 


\section{APPENDIX}

\section{ASSOCIATION BETWEEN CELL-PHONE USE COMPLAINTS AND COLLISIONS}

There has been considerable concern about the safety consequences of driver distractions associated with cell-phone use. In the transit industry, safety concerns have largely focused on rail operations. In the present study, a sub-category of the archived customer relations database specifically addresses complaints about operator cell-phone use. The number of complaints logged over the three-year study period (387) is too limited to treat cell-phone complaints separately in the signup-level model. Thus, a contingency analysis of the general correspondence between operators' collision involvement and receipt of cell-phone complaints is presented below. The contingency analysis encompasses the three-year study period and relates the receipt of one or more cell-phone complaints during the period to the involvement in one or more collisions.

Table A-1 presents the observed and contingent (i.e., expected under the null hypothesis) cell-phone complaint and collision involvement frequencies for the 1,502 operators covered in the study. A Chi-Square test of the equivalence of observed and expected frequencies in the table is rejected at $\mathrm{p}<.001$ (with a calculated Chi-Square value of 12.27 versus a critical value of 10.8 ). As the table shows, the observed collision involvement of operators who were the subject of one or more complaints about cellphone use exceeded their expected involvement by $13.0 \%$.

Table A-1 Observed and Expected Frequencies of Cell-Phone Complaints and Collision Involvement, 2006-09

(Observed/Expected, 1,502 operators)

\begin{tabular}{|c|l|c|c|}
\cline { 3 - 4 } \multicolumn{2}{c|}{} & \multicolumn{2}{c|}{ Cell-Phone Complaint(s)? } \\
\cline { 3 - 4 } \multicolumn{2}{c|}{} & Yes & No \\
\hline & Yes & $200 / 177$ & $894 / 916$ \\
\hline Collision(s)? & & & $364 / 342$ \\
\hline & No & $44 / 66$ & \\
\hline
\end{tabular}




\section{SO OTREC \\ AND EDUCATION CONSORTIUM}

P.O. Box 751

Portland, OR 97207

OTREC is dedicated to stimulating and conducting collaborative multi-disciplinary research on multi-modal surface transportation issues, educating a diverse array of current practitioners and future leaders in the transportation field, and encouraging implementation of relevant research results. 